\title{
The Impact of the Real Estate Crisis on a South European Metropolis: From Urban Diffusion to Reurbanisation
}

\author{
Massimiliano Crisci $^{1}$ iD
}

Received: 11 September 2020 / Accepted: 21 July 2021 / Published online: 24 August 2021

(c) The Author(s) 2021

\begin{abstract}
Beginning in the 1970s, the urban core of the Rome Metropolitan Area (RMA) experienced four decades of intense depopulation and urban diffusion, which caused a considerable social impact. On the basis of an original dataset on residential mobility within the city of Rome, this paper aims to show that the RMA is currently experiencing a new stage of reurbanisation resulting from the bursting of the housing bubble after the 2008 crisis. Unlike other European contexts, the RMA repopulation is lacking forms of "urban resurgence" and is taking place in one of the most difficult periods of the city's recent history. Paradoxically, the trend of private real estate market succeeded to stop urban sprawl where for a long time public decision-maker had failed. This created an opportunity to finally govern the process and steadily halt the urban diffusion, implementing targeted residential densification measures aimed at stabilising the demographic recovery of the urban core and preventing a return to urban sprawl.
\end{abstract}

Keywords Reurbanisation · Urban sprawl · Residential mobility · Housing · Densification · Rome

\section{Introduction}

Between the 1970s and the early 2000s, the urban core of the Rome Metropolitan Area (RMA) experienced an intense and chaotic urban sprawl that triggered a downward spiral of population loss with severe social and economic impact. In this period, the inner city ${ }^{1}$ has lost more than 700,000 residents, that is one-third of its

\footnotetext{
1 In this paper, the terms "urban core", "inner city", "compact city" and "consolidated city" are used as synonyms and refer to a large part of the city representing the core of a metropolitan area.

Massimiliano Crisci

m.crisci@irpps.cnr.it

1 Italian National Research Council, Institute for Research on Population and Social Policies (CNR-IRPPS), via Palestro 32, 00185 Rome, Italy
} 
population, due to a persistent negative migration and natural balance. The outward moves were especially motivated by the unaffordability of housing prices and only partly by the desire to benefit from less overcrowded living conditions outside of the city.

Thanks to an original dataset on the residential mobility from, to and within the city of Rome, this paper will show that the compact city's demographic decline finally ended in the second decade of the 2000s. The bursting of the housing bubble after the 2008 crisis, in fact, led to a containment of outward residential mobility from the RMA's urban core, which became once more appealing for "peri-urban" families, thus giving start to a reurbanisation process.

Generally speaking, the literature uses the concept of reurbanisation to emphasise the different types of changes that take place in the inner cities (Champion \& Congdon, 1988; Couch et al., 2009; Haase et al., 2010; Ogden \& Hall, 2000; van den Berg et al., 1982). At times, such changes can be quantitative, with an increased stock of residents or a rise in in-migration flows; other times, they can be qualitative, as in the case of social diversification processes - which fall within the gentrification paradigm - typical of the "second demographic transition" (Buzar et al., 2007a, 2007b; Cheshire, 2006; Rérat, 2012).

Already in the late 1980s, various cities in Northern Europe started to experience reurbanisation (Champion, 2001; Nyström, 1992), while in Southern Europe the phenomenon took place subsequently and in a limited number of urban areas (Bayona-i-Carrasco et al., 2018; López-Gay, 2014). In Italy, the concept of reurbanisation was hardly used even in the 2000s (Buzar et al., 2007a, 2007b).

Using elements typical of both population studies and housing studies (Couch et al., 2009; Kabisch et al., 2019; Myers, 1990), in this paper reurbanisation refers to the end of depopulation in the urban core, and the passage from a stage characterised by a strong migratory loss to another stage marked by a restored balance with metropolitan rings. In particular, the work highlights how in the RMA the process occurred in the absence of an "urban resurgence", developing a singular "reurbanisation path" during a phase in which the urban context was clearly experiencing difficulty and socio-economic decline.

The RMA is also a relevant case study because in this context, paradoxically, the trend of private housing market succeeded in halting urban diffusion where for a long time the public decision-maker had failed, with a strong social impact on the quality of life of the peri-urban population (Crisci, 2019). Although the RMA ranks fifth among the EU urban areas in terms of population, few studies have been conducted on its residential dynamics, lacking detailed territorial microdata, such as those presented in this paper. The work refers to microdata collected from 2003 to 2016 - concerning the RMA's in-migration and out-migration flows, and the residential mobility among districts within the municipality of Rome-that are very rarely shared by the statistical offices of the Italian municipalities.

The paper is structured as follows. The next paragraph provides a review of the literature on reurbanisation in Southern Europe, associating it with the dynamics of the housing market and the 2008 economic crisis. Paragraph 3 describes the territory's context and provides the statistical sources used in this work. Section 4 illustrates the RMA's transition from urban diffusion to reurbanisation after the 2008 
crisis, while Sect. 5 highlights the impact of the trend of the housing market as a crucial factor related to the sharp decrease in residential mobility from the urban core. Paragraph 6 covers the peculiarities of the RMA that contributed towards a reurbanisation without "urban resurgence", suggesting the implementation of residential densification policies aimed at stabilising the demographic recovery of the urban core and preventing a return to urban sprawl. The last paragraph provides some final observations.

\section{Reurbanisation, Economic Crisis and Housing Dynamics in the Large Urban Areas of Southern Europe: A Literature Review}

Beginning in the 1970s, the urban cores of the metropolitan areas of Southern Europe experienced a demographic decline mainly due to urban sprawl. However, the issue was analysed considering such paradigm only in the 2000s, emphasising the many imbalances at environmental, social and economic level (Catalàn et al., 2008; Couch et al., 2007; EEA, 2006; Muñoz, 2003; Petsimeris, 2002; Salvati \& Gargiulo Morelli, 2014).

From the late 1990s, intense international migrations involving the countries of the northern shores of the Mediterranean fostered a demographic recovery of the urban cores, which in part compensated for the persistent outward residential mobility towards the hinterland (Champion, 2001). At the same time, the redensification and the social diversification that took place in many inner cities were considered effects of the "second demographic transition" (Buzar et al., 2007a, 2007b), that is, a consequence of socio-cultural and economic changes that produced considerable repercussions on family structures (van de Kaa, 1987).

This new appeal of the inner cities in Southern Europe recalled what had occurred in the 1980s in various mature urban areas of Central-Northern Europe, such as London and Paris (Champion \& Congdon, 1988; Hall \& Odgen, 2003), where the demographic recovery of the urban cores had led to a reurbanisation after a period of decline.

In the classic urban life cycle model (van den Berg et al., 1982), reurbanisation recalls the fourth and last stage, which should follow the urbanisation, suburbanisation and deurbanisation stages. This last stage relates to the development of a functional urban region (FUR), inverting the trend of the two stages that preceded it, during which the population of the inner city decreases or shows a much slower growth than the suburban rings. Basically, in said model, reurbanisation represents the stage where there is a first demographic recovery of the urban core that could lead to a wider revival of the entire FUR.

Although the concept of reurbanisation has not been sufficiently formalised (Buzar et al., 2007b), the term has had a quite extensive use within the scope of urban studies even apart from the urban life cycle model, but with different meanings, following quantitative or qualitative approaches (Rérat, 2012). Various quantitative studies have talked about reurbanisation when referring to situations of demographic turnaround, often due to international in-migration flows (Champion, 2001). Depending on the countries and the availability of statistical sources, 
some contributions have highlighted a reurbanisation process of an area based on: a broad series of indicators (Kabisch et al., 2019); the stock of individuals or families residing in the area (Buzar et al., 2007a); the in-migration and out-migration flows, through a migration balance (Rérat, 2012), residential flows among the municipalities of the metropolitan area, or intra-urban mobility among districts of the core city (Bayona-i-Carrasco et al., 2018; Crisci \& Santacroce, 2019; López-Gay, 2014), as the present work will do.

Apart from the current demographic trends, the term reurbanisation has also been used from a qualitative perspective as a synonym for urban regeneration or renewal, with particular reference to urban evolution in specific districts (Bourne, 1996). Other authors, instead, have used the concept of reurbanisation to talk about processes connected to the second demographic transition through an approach that is quantitative only in part (Ogden \& Hall, 2000).

For a long time, urban sprawl was a dominant theme in Southern European countries, but in recent years various scholars have started to study the emerging phenomenon of reurbanisation, especially in Spain and Italy. In Spain, various studies in the 2000s highlighted a recovery of the population of the urban cores connected initially to international migrations (López-Gay, 2014). Some studies traced the 2008 crisis back to the sprawl reduction and the standstill of a development model firmly based on the construction sector, as in the case of Madrid (Díaz-Pacheco \& GarcíaPalomares, 2014) and Barcelona (García-Coll \& López-Villanueva, 2018). On the whole, the inner cities of the main Spanish urban areas continued to lose residents, although to a lesser extent (Bayona-i-Carrasco et al., 2018; Gil-Alonso et al., 2016).

In Italy, episodes of "return to the city" have been highlighted in several big urban areas, ascribable also to the gentrification paradigm (Buzar et al., 2007a) and to international migrations (Conforti et al., 2013). After the 2008 crisis, the housing trends changed and in all the main Italian urban areas, a decrease in outward residential mobility has since been registered, as well as an increase in inward moves (Benassi et al., 2019). In the metropolitan area of Rome, the decrease in urban sprawl was particularly intense and ascribed to the sharp decrease in housing prices after the economic crisis, which increased the supply of affordable houses (Crisci \& Santacroce, 2019).

Compared to other regions of the Western world, the economies of the countries of Southern Europe recovered with more difficulty from the effects of the 2008 crisis (Ball, 2014) and, as highlighted by the literature, the bursting of the housing bubble both in Italy and in Spain had consequences even on residential mobility in the urban areas. In metropolitan areas of Spain, the 2008 real estate crisis has slowed down urban growth and residential mobility towards the suburban municipalities, due to the fall of international migration in the urban cores and the decrease of periurban moves of Spaniards, linked to the restriction on mortgage lending (Gil Alonso et al., 2016), although according several authors the amount of residential moves has only slightly decreased (Bayona-i-Carrasco et al., 2018; Pujadas et al., 2016). The diffusion of the homeownership in Southern European countries has been highlighted as a relevant factor in explaining immobility in a conjuncture characterized by decreasing job opportunities and insecurity, when purchasing and selling property is both more difficult than 
previously as well as more time consuming (Morrison \& Clark, 2011; PalomaresLinares \& van Ham, 2016). At the same time, other authors have showed that changes in demographic structure can have had an impact on residential moves in the post-crisis period. For instance, in Spain the demand for main residences has been affected by a decrease in the number of new households, due to the smaller size of the generation of young adults that are accessing to the housing market (Módenes \& López-Colás, 2014).

Indeed, in order to grasp the decisive factors of families' moves from a micro perspective (Courgeau, 1985; Mulder, 2007), and of the housing dynamics between urban core and rings from a macro perspective (Kabisch et al., 2019), it is necessary to consider elements such as the purchase price and the lease price of flats, or composition of the housing supply.

This paper refers to reurbanisation in its quantitative meaning, highlighting the beginning of a new stage of urban development in the RMA characterised by a demographic revival of the urban core, consisting in the sharp reduction of urban sprawl resulting from the significant changes that occurred in the housing market, especially after the 2008 economic crisis. This contribution is based on a dataset on residential flows of the RMA, presented in the following paragraph.

\section{Studying the Residential Mobility of Rome: Statistical Sources and territorial Context}

The statistical sources on stocks and flows of the RMA population have suffered limitations for a long time. In this paper, residential mobility is analysed using original databases that allowed us to overcome some of the shortcomings.

With regard to the stock of Rome's population, up to 2014 the statistical sources were significantly inconsistent: the population register overestimated the number of residents by more than 100,000 units, while the latest censuses (2001 and 2011) have underestimated it by 150,000-200,000 units. By failing to consider this problem, many publications on Rome have produced strongly distorted interpretations on the demographic dynamics of the last decades.

Therefore, in this paper the following stock data from the Anagrafe (population register) of the Municipality of Rome for the 2003-2017 period (as at 1st January of each year) have been used:

- for the years 2003, 2008 and 2009: data accurately "rebuilt" and corrected after the 2001 census within the scope of a research project funded by the Municipality of Rome (Sonnino et al., 2011);

- from 2014 to 2017: data re-aligned and corrected after the 2011 census by the Statistical Office of Rome (Roma Capitale, 2015).

- for the remaining years (2004-2007 and 2010-2013): stock data broken down by urban areas (see Fig. 1) have been obtained through a linear regression based on the correct data available. 


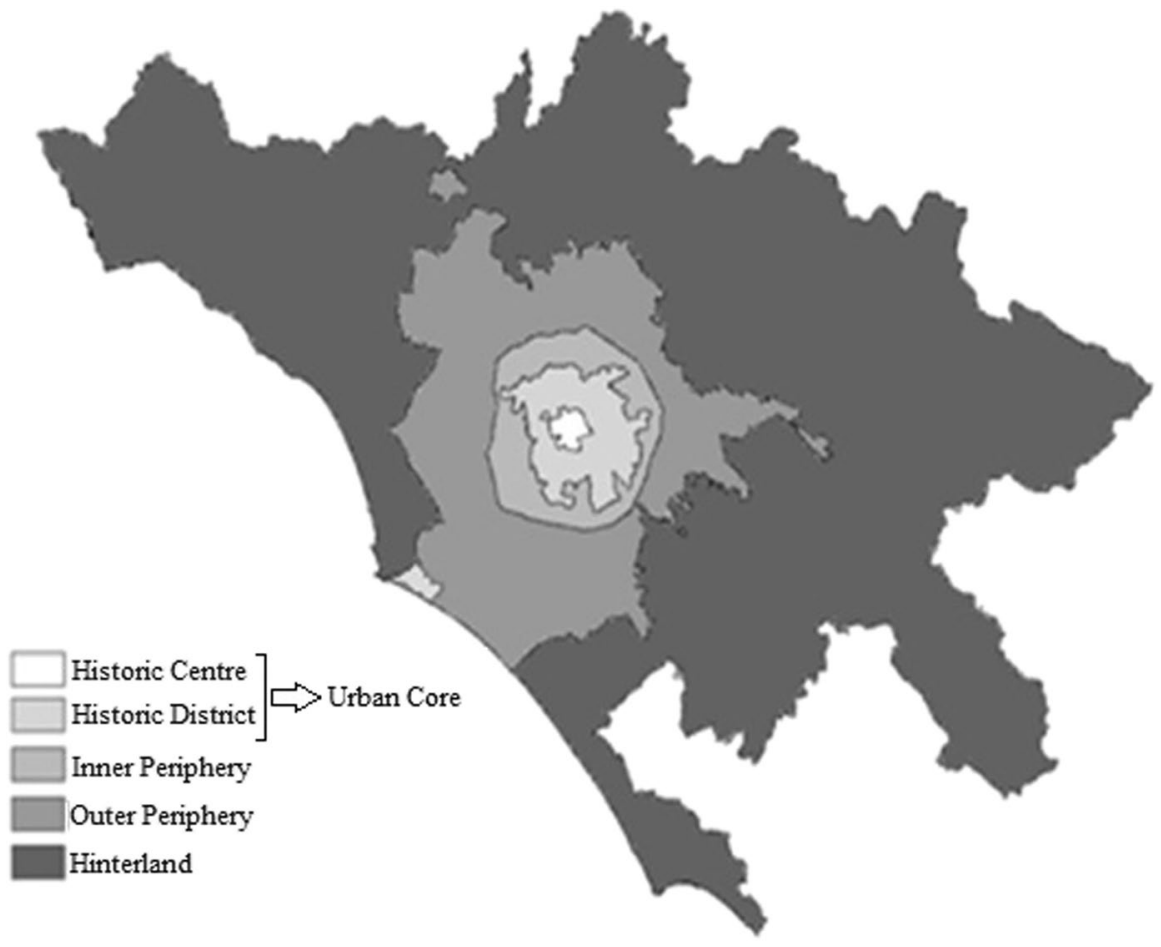

Fig. 1 The division of the Rome Metropolitan Area (RMA) into urban areas

Between the late 1960s and the early 2000s, statistics on residential mobility flows in the area of Rome were significantly lacking: very few aggregated data were available on residential mobility to and from Rome, while there was no information on moves within the city.

In this paper, use has been made of a wide set of population register microdata provided by the Municipality of Rome, disaggregated by 155 urban zones of residence and by area of origin/destination of the move (urban zone of Rome; other municipality of the RMA; other Italian province; foreign country). The flows dataset refers to the 2003-2016 period and is composed of three population register archives that include an annual average of moves equal to about: 60,000 in-migration flows to Rome from the rest of Italy and foreign countries; 45,000 out-migration flows from Rome to the rest of Italy and foreign countries; 120,000 moves within Rome among urban zones. ${ }^{2}$

With its $1285 \mathrm{~km}^{2}$, the surface of the municipality of Rome is the largest in Italy, and ranks first in the EU. Moreover, it has an extremely variable residential density

\footnotetext{
${ }^{2}$ The timing of the registration of the move in the Anagrafe may be different from the timing of the actual "residential mobility". This data bias is distributed along the whole considered period and do not affect the interpretation of the trend of the flows.
} 
between central and peripheral areas, and includes very vast portions of farmland (the Agro romano). Since the territory of the municipality of Rome is too extensive to be considered the urban core, the RMA was divided into four urban areas (Fig. 1) in order to analyse the dynamics of the population stocks and flows between RMA's core and ring. In particular, three areas were identified within the municipality of Rome (Urban Core, Inner Periphery, Outer Periphery), obtained by aggregating Rome's 155 urban zones, and one externally (the Hinterland), including the other 120 municipalities of the RMA.

The Urban Core includes the most ancient centre of the city (Historic Centre), with a very high concentration of tourists and managerial services, and the surrounding area of the Historic Districts, including the districts of the "consolidated" city built in the twentieth century, which in the last 50 years have undergone only minor urban changes. Some of the Historic Districts closer to the Historic Centre share its tourist and production concentration, while those more distant from the centre are mainly residential and also include wide public building zones. The two areas of the Inner and Outer Periphery contain, instead, the more recently built districts that became populated especially starting from the 1970s, and include many districts that used to be illegal and still lack services and infrastructure. In particular, the Outer Periphery includes the vast area of the municipality of Rome on the outside of the urban highway of the Great Ring Road (GRA). Such area is occupied mostly by farmland and has a very low residential density. The Hinterland of the RMA includes 120 municipalities, most of which with a low number of inhabitants (between a minimum of 150 and a maximum of 90,000 residents) strongly dependent on Rome's inner city, where most of the jobs in the area are concentrated. In the last decades, the first and second ring areas of the Hinterland have received hundreds of thousands of new residents coming from Rome, many of whom commute every day to study and work in the capital.

On the basis of such data and territorial grid, the following paragraph highlights the new residential dynamics started in the 2000s, and in particular the beginning of a reurbanisation process in the RMA's Urban Core.

\section{Rome's Area from Urban Diffusion to Reurbanisation}

The level of urban concentration in the RMA reached its peak in the early 1970s, with the Urban Core that hosted more than 2.2 million residents. In the following four decades, a progressive depopulation of the urban core took place and the compact city of Rome lost 700,000 inhabitants, almost one-third of the population (Crisci, 2010). The positive balance of the international migration was not sufficient to compensate the losses resulting from the natural negative balance and, especially, from the urban sprawl. In the 1970s and 1980s, in fact, many residents moved to the urban and metropolitan peripheries, where many illegal houses were built. Such extra legem self-construction process (the abusivismo) was fuelled by the families' need for houses and the speculative interests of builders and landowners (Clementi \& Perego, 1983; Della Seta \& Della Seta, 1988; Insolera, 2011). Apart from those economic grounds, the diffusive process developed also due to a preference for a 
less congested environment and detached houses, not much present in the consolidated city (Cellamare, 2016).

As of the 1990s, many districts of the Urban Core have become less congested, leading to an improvement in the quality of life (Tocci, 2020). At the same time, the number of new constructions of illegal buildings in both the Inner and Outer Peripheries has decreased significantly. However, urban diffusion continued, becoming more and more a constraint rather than a choice, given the unaffordability of housing prices in the Urban Core. This diffusion was mainly caused by middle-low income young families, forced to move to neighbourhoods with low connectivity (Crisci, 2019). Therefore, the peri-urban families suffered from a situation of social inequality linked also to the wide use of the private vehicle in a city like Rome, which ranks second worldwide and first in Europe as to time lost in traffic (Inrix, 2019). Moreover, the permanence of the elderly in the Urban Core affected the relationships and bonds of mutual aid and assistance between generations of the same family, which to a large extent lies at the basis of the Italian welfare system (Crisci, 2010).

Between 2009 and 2017, depopulation of the RMA's Urban Core stopped, and the number of residents levelled off slightly above 1.5 million. A reurbanisation process began, supported by a positive total net migration that compensated the increasingly negative natural dynamics, ever more intense in the neighbourhoods closer to the city centre, where the population is older and the deaths more numerous and where the natality is lower, due to the old age structure and the selection effect of the real estate prices on the families with small children. ${ }^{3}$

Within the framework of a general appeal of the Urban Core as to migrations coming from the rest of Italy and abroad (Fig. 2), beginning with the 2006-2008 period, the inner city experienced a recovery of the net migration rate, mainly owing to the evident improvement of the balance with the rest of the RMA.

The overall reduction of the urban diffusion results very evident by observing the residential mobility within the RMA (Fig. 3), with a systematic increase in the net migration rate in the more central areas, and a decrease in the more peripheral areas. The decrease is particularly evident when considering the trend of the net migration between each one of the three peripheral urban areas and the Urban Core, with values still negative but 4-6 times lower in a few years. The drop in urban sprawl is a generalised phenomenon that occurs even between the urban areas at a greater distance from the compact city: between the Inner Periphery and the two more outer areas; between the Outer Periphery and the Hinterland.

Over the last decade, the Urban Core has improved its net migration rate with the rest of the RMA, primarily due to the decrease in out-migration flows, rather than the increase of in-migration flows (Fig. 4). In fact, between 2005 and 2016 the outmigration flow rate of the Urban Core declined from 19.9 to 11.6 per 1000, while

\footnotetext{
3 In the RMA, the average annual natural rate of the Urban Core was equal to -2.6 per 1000 inhabitants in the period 2003-2008 and decreased to - 3.5 per 1000 in 2009-2016, whereas the average annual net migration rate increased from -1.8 per 1000 in the pre-crisis years, to +6.7 per 1000 in the post-crisis period.
} 


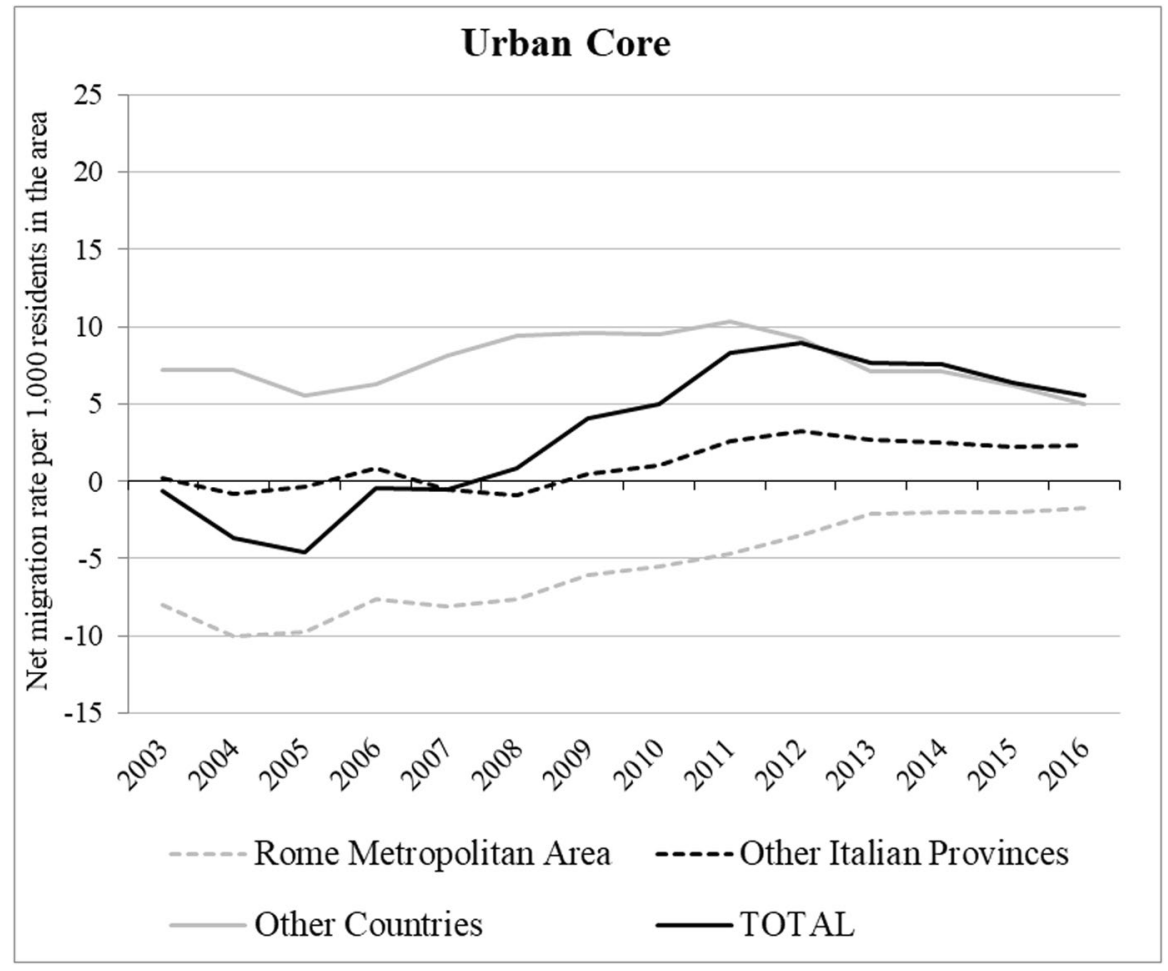

Fig. 2 Net migration rate of the Urban Core by urban area of the RMA, 2003-2016. Values per 1000 residents in the Urban Core. Source Author's elaboration based on population register data

the in-migration flow rate remained stable for a long time around 10 per 1000 , reaching its peak in 2012 (12.6 per 1000), and then gradually decreasing. Said trends are broadly noticeable in the mutual exchange with the three rings of the RMA.

The total residential mobility rate (TRMR) allows the analysis of the intensity of the moves between the urban areas of the RMA without the distortion of the volume and the age structure of the population. ${ }^{4}$ Considering the matrix origin-destination of the TRMR values with reference to the RMA urban areas in two periods (2003-2008 and 2009-2016), it's possible to determine the impact of economic crisis on the variation of residential mobility along the axis centre-periphery (Tab. 1). After the crisis the centrifugal mobility in the RMA has strongly fallen. On the whole, the rate of the Urban Core decreased by $-17.5 \%$ and residential mobility fell towards both Urban Periphery $(-14.9 \%)$ and the Hinterland $(-21.8 \%)$. The decline of the TRMR from Urban Periphery to the Hinterland was also sharp (- 25.5\%), whereas the moves from the Hinterland towards the Urban Core and the Urban

\footnotetext{
4 The TRMR indicates the amount of residential mobility that a person would make in the life if he/ she had permanently the age-specific internal migration rates of a particular period of time (Bayona-iCarrasco et al., 2018).
} 

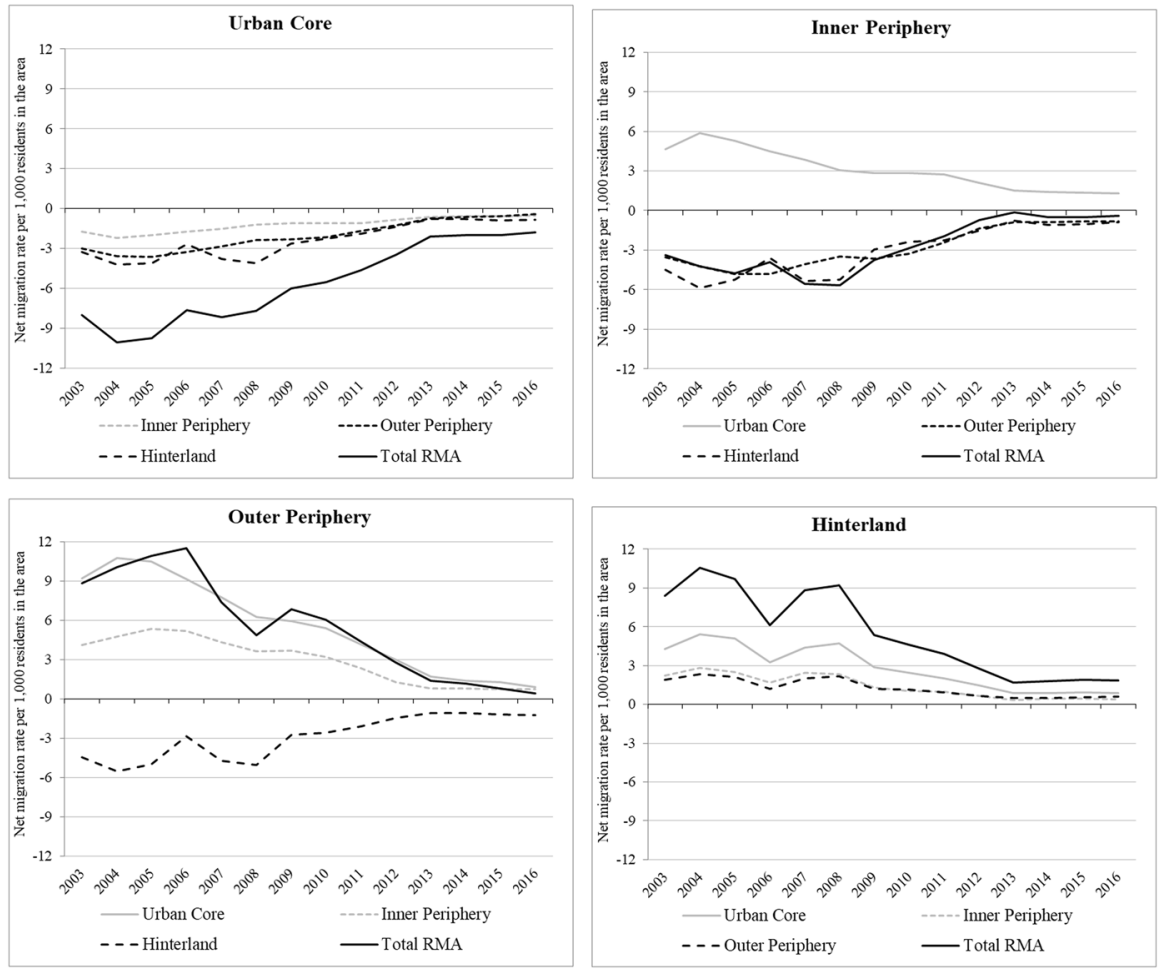

Fig. 3 Net migration rate between the urban areas of the RMA, 2003-2016. Values per 1000 residents in the urban area. Source Author's elaboration based on population register data
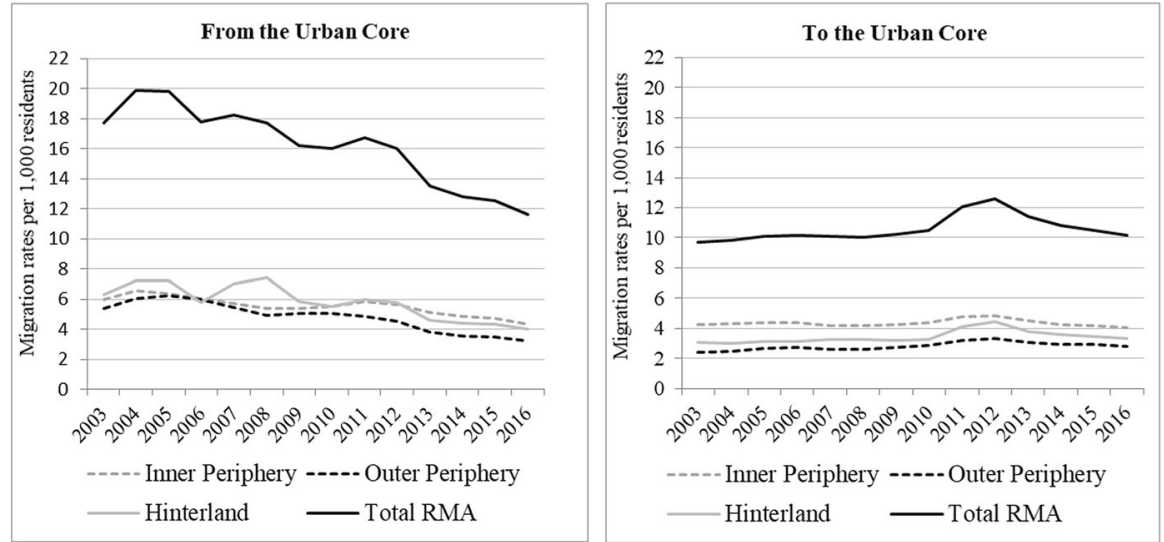

Fig. 4 Migration rates from/to the Urban Core by urban area of the RMA, 2003-2016. Values per 1000 residents in the urban core. Source Author's elaboration based on population register data 
Table 1 Total residential mobility rates (TRMR) between the areas of the RMA by period (2003-2008 and 2009-2016)

\begin{tabular}{|c|c|c|c|c|}
\hline \multirow[t]{2}{*}{ Areas of origin } & \multicolumn{3}{|c|}{ Areas of destination } & \multirow[b]{2}{*}{ Total } \\
\hline & Urban core & Urban periphery & Hinterland & \\
\hline \multicolumn{5}{|c|}{ Pre-crisis period (2003-2008) } \\
\hline Urban core & - & 0.94 & 0.56 & 1.50 \\
\hline Urban periphery & 0.68 & - & 0.76 & 1.45 \\
\hline Hinterland & 0.31 & 0.35 & - & 0.66 \\
\hline \multicolumn{5}{|c|}{ Post-crisis period (2009-2016) } \\
\hline Urban core & - & 0.80 & 0.44 & 1.24 \\
\hline Urban periphery & 0.69 & - & 0.57 & 1.26 \\
\hline Hinterland & 0.32 & 0.38 & - & 0.70 \\
\hline \multicolumn{5}{|l|}{ Variation $(\%)$} \\
\hline Urban core & - & -14.9 & -21.8 & -17.5 \\
\hline Urban periphery & 0.4 & - & -25.5 & -13.3 \\
\hline Hinterland & 2.6 & 8.4 & - & 5.7 \\
\hline
\end{tabular}

The area "Urban periphery" includes inner and outer periphery. Source: Author's elaboration based on population register data

Periphery has risen by $5.7 \%$. These results confirm that during the post-crisis period in the RMA the trend reversed from residential diffusion to reurbanisation (Table 1).

The following paragraph highlights the impact of the housing dynamics on residential mobility in the RMA, putting in relation the evolution of the housing cycle with the reduction of the centrifugal flows, especially from the Urban Core, which are at the basis of a large part of the RMA's reurbanisation process.

\section{The Causes of the Decline in Urban Diffusion: The Local Housing Bubble and the Global Financial Crisis}

The economic and urban evolution of Rome-administrative capital that did not experience an industrial development-has always been deeply conditioned by the construction sector and housing dynamics (Insolera, 2011). This section highlights how such dynamics in the first two decades of the twenty-first century was peculiar compared to the national framework, and played a central role even in the quick reduction of urban diffusion, and the beginning of a reurbanisation stage in the RMA.

Between the mid-1990s and 2016, the Italian housing market experienced three main stages, definable on the basis of the trend of trading volume (Guerrieri et al., 2018) (Fig. 5): an increase from 1996 to 2006; a period of crisis in 2007-2012; a recovery starting from 2013. Even Rome's housing market went through stages with the same duration, with a drop in trading one year before the national decrease (2006), a much more consistent price increase between 2000 and 2008 (equal to $+100 \%$, against about $+55 \%$ of the national average), and a much more 


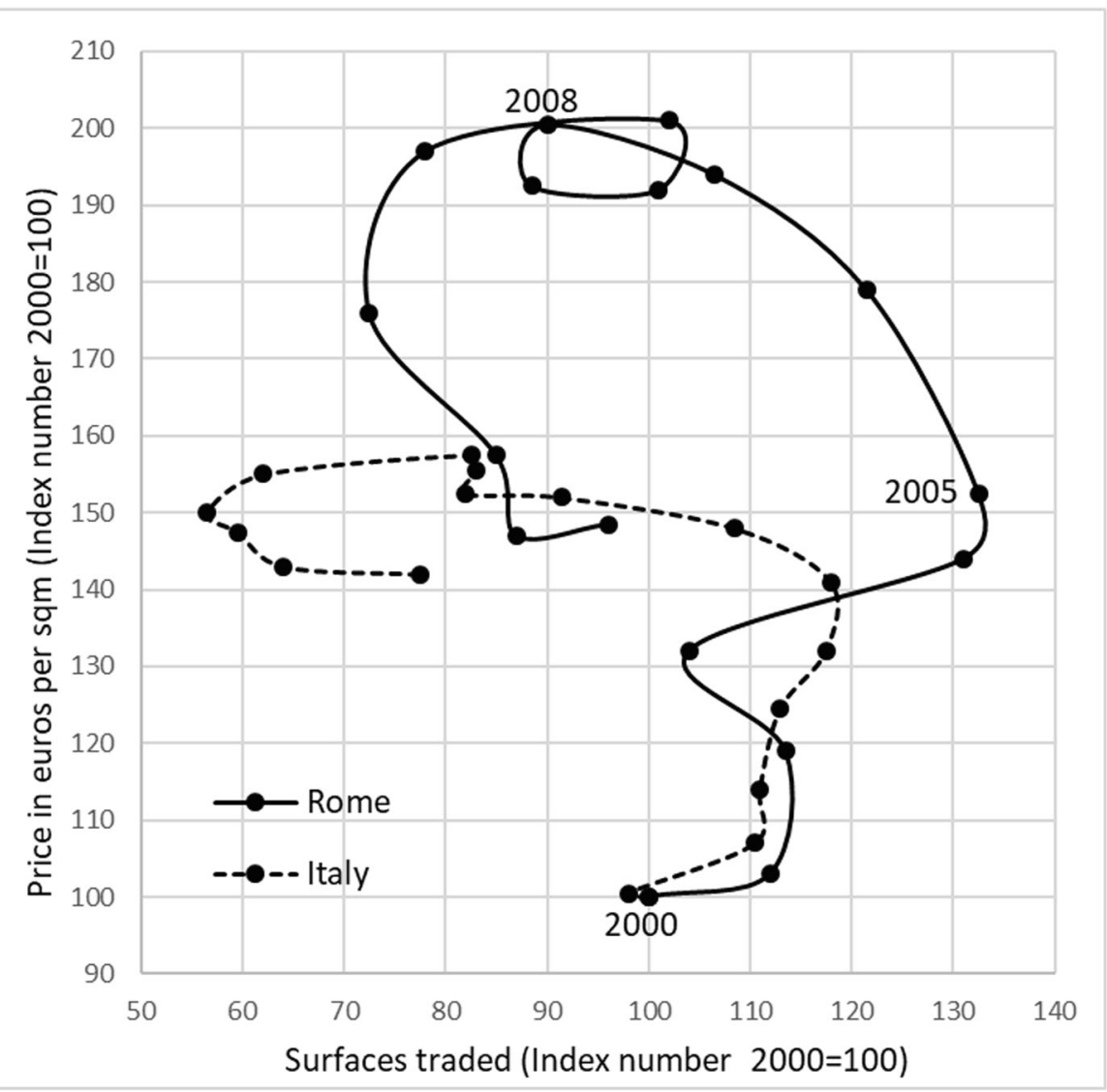

Fig. 5 The housing cycle in Rome and Italy. Prices (in Euros per square metre) and surfaces traded from 2000 to 2016. Index numbers, year $2000=100$. Source Italian Real Estate Market Observatory-Revenue Agency. Figure reprocessed from Guerrieri et al. (2018)

substantial decline in housing values compared to the Italian average between 2009 and 2016 , about $-55 \%$ against $-18 \%$.

Therefore, in the 2000s Rome's housing market experienced a much higher reactivity compared to the national average with regard both to the volume of trading and the housing prices. Macroeconomic factors affecting housing supply and demand, first of all the dynamics of housing prices and mortgage interest rates, caused the sharp reduction of the out-migration flows from the compact city, and contributed to interrupting the depopulation. Four stages can be identified in the trend of centrifugal flows from the Urban Core in 2003-2016 (Fig. 6).

(1) In the 2003-2005 period, the high rates of out-migration flows from the Urban Core (19.9 per 1000 in 2005) coincided with an expansive conjuncture in Rome's housing market, fostered by the gradual decrease in the interest rates in the 


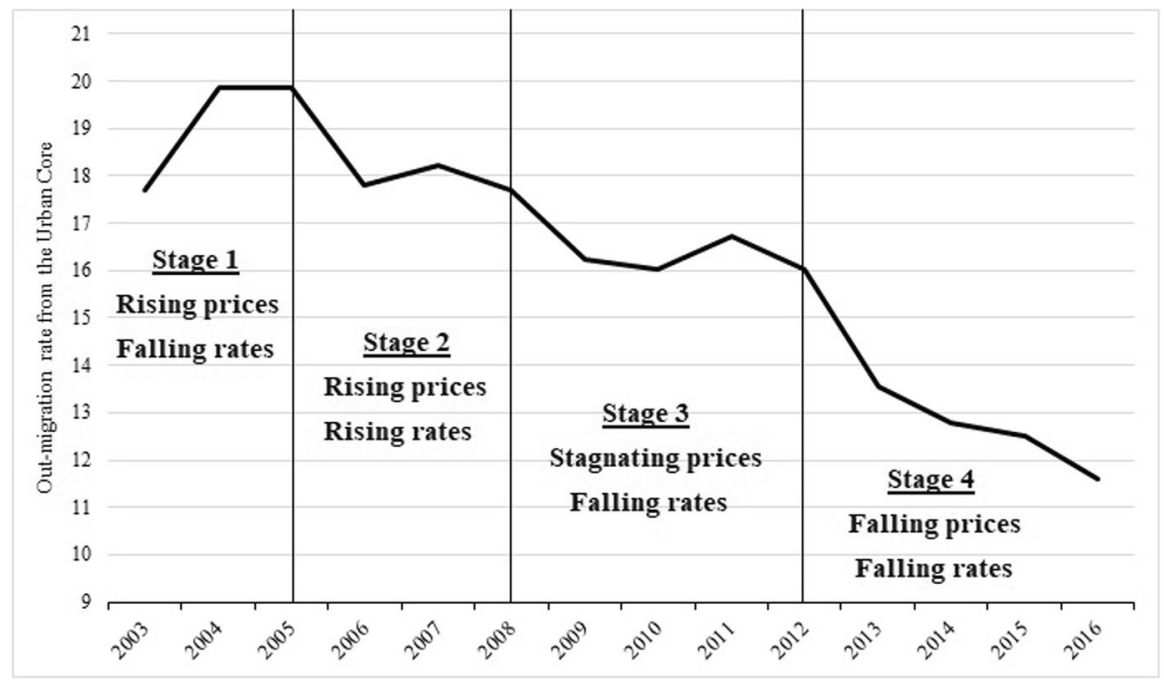

Fig. 6 Out-migration rates from the Urban Core to the rest of the RMA and trend of housing prices and interest rates on mortgages, 2003-2016. Source Author's elaboration based on population register data

late 1990s. In this stage, even the Italian macroeconomic context—with a positive GDP growth rate and the level of wages moving upwards (Guerrieri et al., 2018) — fostered the families' and housing investors' availability to purchase, and the increasing demand for houses, which in turn produced a rise in prices. Therefore, the high levels of urban diffusion identified in the RMA in this stage seem to be linked primarily to the substantial differential of the housing prices along the centre-periphery axis.

(2) Beginning with 2006, the housing market in the RMA experienced a first crisis. Initially, it was an "endogenous" crisis, that is, one triggered by two variables that intervened directly on the trend of the real estate market: interest rates and prices. The sudden increase in mortgage interest rates in Italy $(+1.8 \%$ in 2006-2007) and the sharp rise in housing prices (almost $+50 \%$ in 2006-2008) determined a drop in trading — as highlighted above (Fig. 5). At the same time, the out-migration flows from the Urban Core to the rest of the RMA decreased, from 19.9 per 1000 in 2005 to 17.7 per 1000 in 2008.

(3) With the 2008 financial crisis, housing prices in the RMA finally stopped rising, while trading further decreased. The sharp national cut in interest rates on mortgages, equal to $-3 \%$ between 2008 and 2010, was not sufficient to invert the trend. The Italian economic situation, characterised by a definitely negative GDP and a severe drop in employment rates, depressed the future expectations of families and housing demand. At the same time, banks became much more prudent in giving loans compared to the past. In such unstable economic situation-triggered this time by an "exogenous" factor such as the global crisis- the out-migration flows from the Urban Core further dropped and, after a slight recovery, they stabilised around 16 per 1000 in 2012. 
(4) In 2011-2012, Italy underwent a further economic shock due to the crisis of the sovereign debt ${ }^{5}$ and a further fall in GDP. The strongly negative economic situation, along with an increase in the taxation on houses, led to a new drop in housing transactions. Trading recovered only in 2013, fostered by three aspects: a further decrease in mortgage interest rates, which dropped from 4.3 to $2.5 \%$, between 2012 and 2016; a less strict credit policy by banks; and a first consistent decrease in housing prices. In particular, the decrease in housing prices triggered the quick decline in the RMA's urban sprawl, causing the out-migration flows from the Urban Core to the rest of the RMA to drop from 16.0 to 11.6 per 1000 in the 2012-2016 period.

What happened in Rome's housing market in this fourth stage represents a crucial moment in the transition from urban sprawl to reurbanisation, whose determinants can be further understood if we observe the dynamics of housing values in the RMA's urban areas between 2011 and 2016, that is, before and after the decrease in prices (Fig. 7).

In the 2011-2016 period, the RMA's overall average housing prices decreased $(-17.3 \%)$, with a higher drop in the areas more distant from the centre, passing from $-12.3 \%$ of the Historic Centre to $-22.3 \%$ of the Hinterland. Therefore, in 2016 the already sharp gap between the average prices of the more central areas (Historic Centre: about 6000 Euros per square metre) and those of the more peripheral areas of the RMA widened (Hinterland: about 1500 Euros per square metre). At the same time, in 2016 the average housing values of the more outer urban areas became analogous to those of the urban areas closer to the city centre registered in 2011.

Basically, in 2016: the average prices of several areas of the Hinterland were equivalent to those registered in 2011 in various areas of the Outer Periphery (about 2200 Euros per square metre); the prices of the Outer Periphery were similar to those of the Inner Periphery five years before (about 2700 Euros per square metre); the prices of the Inner Periphery were close to those of a number of areas of the Historic Districts in 2011 (about 3300 Euros per square metre). In other words, with the same budget many families were able to buy a flat much closer to the centre compared to what they would have been able to buy only a few years before. The drop in housing prices was thus a decisive element in the reduction of Rome's urban diffusion, since it allowed the centrifugal trajectories to be significantly reduced compared to the past.

\section{Discussion}

The bursting of the real estate bubble that followed the 2008 crisis had a remarkable impact on the housing dynamics in the RMA. Indeed, a new stage of reurbanisation began, characterised by a demographic recovery of the inner city, and a sharp

\footnotetext{
5 In the second half of 2011, in a few months the spread between Italy's 10-year BTP bond and the German Bund passed from values below 200-basis points to values above 500 points.
} 


\begin{tabular}{|c|c|c|c|}
\hline Areas & 2011 & 2016 & $\begin{array}{c}\text { Var. } \% \\
\text { 2011-2016 }\end{array}$ \\
\hline HISTORIC CENTRE & 6796 & 5962 & $-12,3$ \\
\hline HISTORIC DISTRICTS & 4432 & 3772 & $-14,9$ \\
\hline Appia Tuscolana & 4012 & 3436 & $-14,4$ \\
\hline Aurelia-Gianicolense & 4090 & 3543 & $-13,4$ \\
\hline Ostiense-Navigatori & 3439 & 3097 & $-9,9$ \\
\hline INNER PERIPHERY & 3343 & 2788 & $-16,6$ \\
\hline Appia-Tuscolana & 3373 & 2709 & $-19,7$ \\
\hline Aurelia & 3187 & 2728 & $-14,4$ \\
\hline Cintura Eur & 3341 & 2735 & $-18,1$ \\
\hline Portuense & 3234 & 2816 & $-12,9$ \\
\hline OUTER PERIPHERY & 2709 & 2252 & $-16,8$ \\
\hline Fuori G.R.A.- EST & 2509 & 2109 & $-15,9$ \\
\hline Fuori G.R.A.- NORD & 2554 & 2269 & $-11,2$ \\
\hline Fuori G.R.A. OVEST & 2604 & 2180 & $-16,3$ \\
\hline Fuori G.R.A. SUD-OVEST & 2948 & 2360 & $-19,9$ \\
\hline HINTERLAND & 2038 & 1584 & $-22,3$ \\
\hline Asse Tiburtina & 2109 & 1621 & $-23,1$ \\
\hline Castelli Romani & 2350 & 1868 & $-20,5$ \\
\hline Litorale Nord & 2307 & 1840 & $-20,2$ \\
\hline Litorale Sud & 2113 & 1614 & $-23,6$ \\
\hline ROME MUNICIPALITY & 3673 & 3083 & $-16,1$ \\
\hline ROME METROPOLITAN AREA & 3082 & 2550 & $-17,3$ \\
\hline
\end{tabular}

Fig. 7 Housing prices by RMA urban area (average values in Euros) and variation (\%), 1st semester 2011 and 2nd semester 2016. Source Italian Real Estate Market Observatory-Revenue Agency. Note: the territorial breakdown of the housing data does not totally correspond to that of the population register data used in the rest of the paper. The Urban Core, as defined up to now, includes the totality of the Historic Centre and Historic District, as well as a small part of the sub-areas of the Inner Periphery

reduction of the intense urban sprawl towards the metropolitan peripheries, which had been going on for four decades. 
The case of Rome leads us to reflect on the elements within a context capable of fostering the beginning of a reurbanisation in a specific area. In this stage, we could have an opportunity in the RMA to address the settlement model and steadily invert the tendency of urban diffusion through residential densification measures.

\section{Reurbanisation Without “Urban Resurgence”}

In different European contexts, especially in central-northern countries, reurbanisation has been associated with positive social and economic situations, characterised by appeal and dynamism, with reference to which terms such as "urban resurgence" or "urban renaissance" have been used (Atkinson, 2004; Cheshire, 2006). Authors as Cheshire (2006) have emphasized the difficulty in defining the concept of "urban resurgence". It has been suggested that a resurgent city has overcome a period of decline and is going through a phase of increasing competitiveness, becoming a more interesting place to live and attracting new activities, particularly in the creative and cultural sectors (Musterd, 2006). Other authors linked urban renewal also to the arrival of new urban population fostering a demographic rejuvenation and to the development of an housing-led reurbanisation (Kabisch et al., 2019; Rérat, 2019).

In the case of Rome, instead, the reurbanisation occurred in one of the most difficult periods of the city's recent history. In the late twentieth century and early $21^{\text {st }}$ the city had lived an expansive period, both economically and culturally, in respect of which it had been talked about a "model Rome" (Clough Marinaro \& Thomassen, 2014), to be proposed and emulated in an Italian urban context not very dynamic at that time. In the last decade, Rome has instead suffered from an economic viewpoint, due to the loss of many jobs and headquarters of large companies in the advanced tertiary sector and to the crisis in the construction sector, a traditionally leading production field, that has displayed a drop in the number of employees and a fall of real estate values (Guerrieri et al., 2018). Even the federalist reforms introduced in Italy have affected the centrality of the capital's public administration, both in terms of funding and employees (Tocci, 2020). Moreover, at a symbolical level, the city has not yet overcome the impact of a judicial inquiry, which in 2014 revealed a widespread illegal conduct in the local ruling class that involved also one of the leading cooperatives that supplied social and environmental services (Povoledo, 2014). ${ }^{6}$ Putting a stop to the criminal management of public affairs consolidated over the years, and the consequent political and administrative instability, made even the normal supply of public services (such as transports, waste, management of green spaces) problematic. As a consequence, according to the opinion of the Rome's residents since 2014 the quality of life in the city decreased dramatically below a sufficient level and has not yet recovered (ASPL, 2019) (Fig. 8). ${ }^{7}$

\footnotetext{
6 The judicial inquiry, that had wide emphasis also in the international press, was called "Mondo di mezzo", and renamed inappropriately even "Mafia Capitale" by the media. In 2019 the final judgement convicted the accused for "criminal conspiracy" and not for "mafia association".

7 The Agency for the Control and Quality of Public Services presents yearly a report to the City Council of Rome including the results of a sample survey on the quality of life of Rome's citizens (ASPL, 2019).
} 


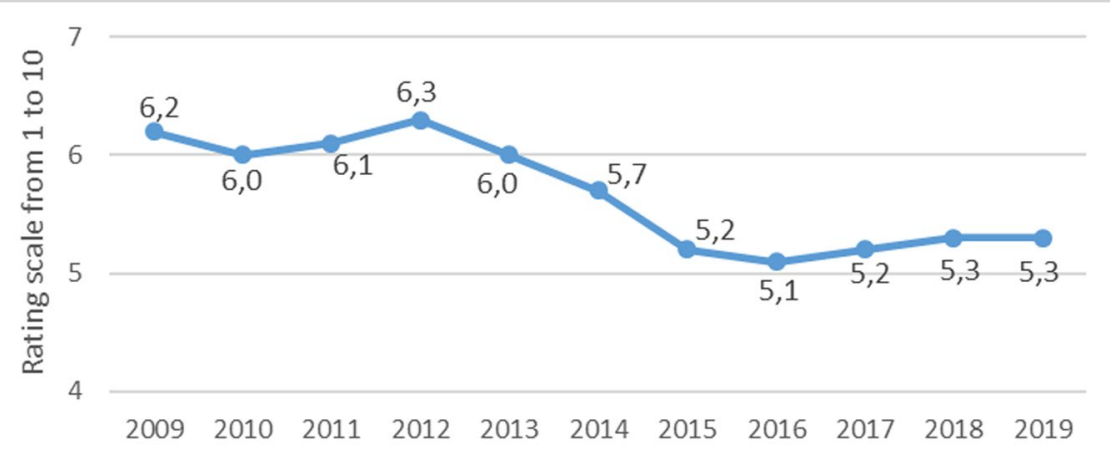

Fig. 8 Evaluation of the quality of life in the city of Rome, 2009-2019. Rating scale from 1 to 10. Source ASPL (2019)

In recent years, "degradation" has become one of the words that the national and international media associate the city with (Horowitz, 2018). Indeed, today's Rome, despite the reurbanisation process it is going through, "is not functioning well". The city seems to be lacking in appeal more than ever, and is distant from the classic canons of the "resurgent city", understood as an urban environment that hosts innovation and economic growth (Musterd, 2006), capable of providing an original contribution to solve the social and environmental challenges (Cheshire, 2006). This situation of low attractiveness is evident also looking at the rankings among 24 of the capital cities of the EU countries that locate Rome at the 18th place in terms of "cultural vibrancy", at the 17th place for "creative economy", at the 22th place for an "enabling environment" (European Commission, 2019; Montalto et al., 2019) and at the 23th in terms of quality of life (European Commission, 2020).

As to the other Mediterranean urban areas in the years following the 2008 crisis, the principal cities in Spain experienced a sharp decrease in urban sprawl, which kept pace with the bursting of the housing bubble (Bayona-i-Carrasco et al., 2018). Beginning with 2014, the negative balance of Madrid's and Barcelona's urban core towards the metropolitan periphery started to increase again, as well as housing prices (Bayona-i-Carrasco \& Pujadas-Rubies, 2019). In the RMA, the outward flows from the urban core have been decreasing for a decade now, and the drop in housing prices started several years after Spain's drop, but is still underway in 2020.

The RMA's "reurbanisation without urban resurgence" has been firstly linked to the will of many families to take the opportunity provided by the fall of real estate prices to stay close to their neighbourhood of origin in the urban core, thereby avoiding an increase in commuting times and undermining the relational and family welfare. At the same time, seem to be significant even the peculiar characteristics of the context, which produce a high differential of urban quality between the districts of the compact city and the areas of the diffused city (largely formed by former illegal buildings), a differential in terms of quantitative provision of services that has also remained in a phase of overall decline in quality of the urban facilities. Today's Rome is very different from the Rome of the 1970s and 1980s, a congested and hyper-dense city which was abandoned 
by many families, even for life choices. Beginning with the mid-1990s, and especially in correspondence with the Jubilee of the year 2000, the town councils raised the quality of services in many districts of the consolidated city, giving rise to changes that in the same period improved use of the urban space for residents even in other European inner cities (Nijkamp \& Kourtit, 2013). Many people born in the districts of Rome's urban core, when leaving their parents' house to start a new family, were no longer able to benefit from the "dividend" of quality of life acquired by the inner city in the previous decades, not out of choice, but because they could not afford a flat in the same area where they had grown up. In fact, the depopulation of the compact city from the 1990s onwards is not mainly due to an "anti-urban" choice of life, but to an imposed choice forced by the conditions of the housing market. Such choice has often resulted in paying the price of an inadequate supply of primary and secondary services - often in districts built illegally, then amended but still lacking "urbanity" —and in many hours spent in traffic every day, in a context of urban inequality along the core-rings axis. In this framework, the rebalancing in the distribution of residents between core and periphery seems to be also the result of a new demand for urban quality that the RMA's rings are not capable of satisfying.

Considering the provision of services in relation of the population can be useful to understand the added benefit of living in the Urban Core of Rome or in its immediate surroundings.

In the Urban Core the index of provision of public and private services (such as cultural, educational, social, health, functional, commercial facilities) ${ }^{8}$ is largely higher than in the urban and metropolitan periphery around the city: 2.5 times more respect to the former informal areas in the Outer Periphery, by $80 \%$ respect to the other zones of the Outer Periphery and by $60 \%$ respect on the first belt municipalities in the Hinterland (AIC-UB, 2010). ${ }^{9}$ This gap between compact city and dispersed metropolitan periphery is even higher if we consider some specific services, such as hospitals, banks, postal offices, libraries, high schools, sport facilities and retail businesses. Moreover, many services in the metropolitan peripheries can be reached only by car, because they are located in a very large and scattered territory that can't be linked efficiently by public transport. That's about as far from an idea of urban accessibility and sustainability, like the walkable/cyclable neighbourhoods of the "15-Minute City", recently proposed also by the mayor of Paris as a way to improve urban quality of life (Moreno et al., 2021).

\section{Governing the Reurbanisation Through Residential Densification Measures?}

For at least four decades, the residential dynamics of the RMA experienced an intense and non-planned urban diffusion, causing substantial territorial imbalances and a remarkable impact on the quality of life and social cohesion (Crisci, 2019;

\footnotetext{
${ }^{8}$ The index of provision of services is equal to the ratio between the numbers of potential users and the amount of available services.

9 These comparative data have been collected within an in-depth research conducted on the social and economic situation of people who live in the former illegal neighbourhoods of the Outer Periphery of Rome (Associazione Italiana Casa, Unione Borgate, 2010).
} 
Insolera, 2011). None of the various local public administrations ever showed interest in governing the urban sprawl and in containing its effects, and the trend of the private housing market steered the residents' spatial distribution between urban core and rings. Although the Metropolitan City of Rome has been established in 2015, a policy vision aiming at governing as a whole the municipality of Rome and the surrounding areas functionally linked to the capital city is still missing. This difficulty in implementing a metropolitan governance is due to diverse motivations. Firstly, the presence of competing objectives between Rome and the other 120 minor municipalities played a role, being the Hinterland municipalities worried about their identity and autonomy, as well as the risk of negative externalities coming from the municipality of Rome (D'Albergo, 2015). Secondly, the huge administrative territory of the capital city (equals to over $1200 \mathrm{~km}^{2}$ ) allowed to develop internally a weak process of metropolisation, functional to the interests of the predominant economic local actors, involved in real estate and construction sectors, who have been able to get wide spaces for building (D'Albergo et al., 2018). The lack of a proper metropolitan vision has had as a consequence an unbalanced development of the whole area that reveal himself also with four decades of urban sprawl.

Paradoxically, the market managed where the public decision-maker had failed: the depopulation of the urban core was interrupted by the fall in housing prices after the 2008 crisis, which triggered a reurbanisation process, allowing many families not to move away from the inner city and many others to move in. Taking advantage of the market's unexpected aid, and keeping into account that the decreasing trend in housing market could stop, the opportunity exists in this stage to finally govern the process and steadily invert the tendency of urban diffusion. The implementation of targeted residential densification measures in specific districts of the RMA's urban core could likely increase the housing supply addressed to residents and contain a new boom in prices. Consequently, the inner city could become a place where it is easier to stay in for the residents and return to for the "peri-urban" citizens. Up to now, the fall in housing prices has reduced the outward residential mobility, but has had more limited effects on the "return" mobility towards the urban core. Those who were forced to purchase a house in the urban and metropolitan periphery at the time of the housing boom may now find it difficult to return to the inner city, due also to the fact that the flats that are more distant from the centre have lost value.

In recent years, the paradigm of the compact city has assumed a central role within the scope of sustainable urban development policies. According to this strategy, in order to prevent urban sprawl it would be desirable to reach a suitable level of density and connectivity in the built areas, and foster a mixed social and economic use of the territory (OECD, 2012). Various authors have highlighted the possible advantages of an urban development model capable of fostering a suitable densification of the inner city. The aim is to consume less land and promote mobility models oriented as much as possible towards ecological and collective means of transport instead of the private vehicle (Florida, 2011). Therefore, the RMA's densification should be targeted and sustainable, in the sense that it should be limited to those central areas that are already well connected and provided with urban infrastructure suitable for receiving further inhabitants: for instance, those neighbourhoods that have suffered the most in the last decades from depopulation, experiencing in 
many cases a drop by more than one-third of residents. Various actions could be implemented to foster the resident families' repopulation of the urban core: fiscal measures to promote the use of the empty flats; restrictions to the proliferation of non-traditional forms of tourist reception (the so-called "airbnbification"); fostering the splitting of large apartments not used or oversize compared to the number of individuals occupying them (often elderly people living alone); recovery and reuse for residential purposes of areas disused for any reason, such as former barracks, store-rooms and warehouses.

\section{Conclusions}

This paper highlighted the recent transition that occurred in the urban core of the RMA from a stage of residential diffusion and depopulation to a reurbanisation phase. The concept of reurbanisation was approached in its quantitative meaning, using an original dataset on residential mobility, drawn from the population register of the municipality of Rome, also including information on intra-urban mobility among districts, rarely released by the Italian statistical offices.

The results of the work show that a new stage in urban development has begun in one of the largest European metropolitan areas, characterised by a decrease in outmigration flows and an increase in in-migration flows, both in the core and in the rings, which could have positive effects on the severe social and economic imbalances produced in the RMA by four decades of urban sprawl. The generalised fall in housing prices, occurred following the 2008 crisis, has allowed many families to take into consideration the housing supply of the urban core-until then unaffordable - and to no longer be forced to move to the metropolitan periphery.

The case of Rome confirms the impact of the trend of the housing market on the residential mobility and reurbanisation processes, as highlighted even in other contexts (Bayona-i-Carrasco et al., 2018; Kabisch et al., 2019). The meeting between housing studies and population studies proves, in fact, to be potentially fertile for both disciplines, due to the strong connections between the two fields of analysis (Myers, 1990; Ogden \& Hall, 2000; Mulder, 2007; Haase et al., 2010).

At the same time, the case of Rome-with its reurbanisation without "urban resurgence" in a stage of drop in international migrations - confirms the difficulty to include the specificities of a local context within the scope of an urban theory. The "path to reurbanisation" followed by the RMA is also the result of peculiarities unlikely repeatable in many other European urban areas. First of all, Rome's position in the centre of a vast "urban desert", which for decades has not put any limits on urban sprawl and exalts its single production centre. Secondly, the large gap between core and rings in terms of quality of life, opportunities and identity, which is represented by the presence, on the one hand, of a historical-cultural heritage unique worldwide in the intra moenia city; on the other hand, by a vast portion of the periphery built on former illegal areas amended, but still lacking a suitable urban quality.

The demographic recovery of Rome's inner city has been underway for a decade now. It seems to be changing from a conjunctural phenomenon, connected to 
a transitory negative dynamics of the housing market, to a structural process that could be linked to an actual cultural change favourable to a "return" to the compact city, an environment both denser in high quality services and providing richer opportunities. Governing the process, through targeted residential densification policies in neighbourhoods with specific characteristics, could foster a long-lasting repopulation of the compact city, allowing the return of former residents, and mitigate the impacts of the urban sprawl. The densification measures that have been proposed here will more likely be implemented successfully if included in the framework of a relaunch of the strategic planning of the Metropolitan City of Rome.

This paper highlighted the transition of the RMA from urban diffusion to reurbanisation, through a macro-territorial approach using quantitative instruments. A deepening of the study could analyse the reurbanisation dynamics in specific portions of the RMA, considering the heterogeneity of the population groups present, also through qualitative instruments and a mixed approach, and allowing the collection of information on specific aspects of residential mobility, such as individual and family motivations and perceptions.

Acknowledgements I thank the two anonymous reviewers whose comments helped improve this manuscript. Research conducted within the context of the International Associated Laboratory «Urban spaces, mobilities, 'citadinité', Southern Europe-Mediterranean Basin (15th-21st centuries)» - LIA MEDITERRAPOLIS.

Funding Not applicable.

Data Availability Not applicable.

\section{Declarations}

Conflict of interest The author declares no conflict of interest.

Open Access This article is licensed under a Creative Commons Attribution 4.0 International License, which permits use, sharing, adaptation, distribution and reproduction in any medium or format, as long as you give appropriate credit to the original author(s) and the source, provide a link to the Creative Commons licence, and indicate if changes were made. The images or other third party material in this article are included in the article's Creative Commons licence, unless indicated otherwise in a credit line to the material. If material is not included in the article's Creative Commons licence and your intended use is not permitted by statutory regulation or exceeds the permitted use, you will need to obtain permission directly from the copyright holder. To view a copy of this licence, visit http://creativecommons.org/licen ses/by/4.0/.

\section{References}

ASPL_Agenzia per il controllo e la qualità dei servizi pubblici locali di Roma Capitale. (2019). XI Indagine sulla qualità della vita e dei servizi pubblici locali a Roma, settembre.

Associazione Italiana Casa \& Unione Borgate (AIC-UB). (2010). Periferie di mezzo. Condizione sociale, economica e territoriale nei quartieri ex abusivi di Roma. Rapporto finale, febbraio.

Atkinson, R. (2004). The evidence on the impact of gentrification: New lessons for the urban renaissance? European Journal of Housing Policy, 4(1), 107-131. https://doi.org/10.1080/1461671042 000215479 
Ball, L. (2014). Long-term damage from the Great Recession in OECD countries. European Journal of Economics and Economic Policies: Intervention, 11(2), 149-160.

Bayona-i-Carrasco, J., \& Pujadas-Rubies, I. (2019). Las grandes áreas metropolitanas en España: del crecimiento y la expansión residencial al estancamiento poblacional. Documents d'Anàlisi Geogràfica.

Bayona-i-Carrasco, J., Gil-Alonso, F., Rubiales-Pérez, M., \& Pujadas-Rubies, I. (2018). New spatial mobility patterns in large Spanish cities: From the economic boom to the great recession. Applied Spatial Analysis and Policy, 11(2), 287-312. https://doi.org/10.1007/s12061-017-9222-x

Benassi, F., Heins, F., \& Tucci, E. (2019). Residential migrations in Italian Metropolitan Local labour market areas: Spatial patterns and age-structure effects. In M. Crisci \& S. Lucciarini (Eds.), Governing inequalities. Inclusion and exclusion processes in the Mediterranean area, from national to city levels (pp. 165-182). Rome: Aracne.

Bourne, L. (1996). Reurbanization, uneven urban development, and the debate on new urban forms. Urban Geography, 17(8), 690-713. https://doi.org/10.2747/0272-3638.17.8.690

Buzar, S., Hall, R., \& Ogden, P. E. (2007a). Beyond gentrification: The demographic reurbanisation of Bologna. Environment and Planning A, 39(1), 64-85. https://doi.org/10.1068/a39109

Buzar, S., Ogden, P., Hall, R., Haase, A., \& Kabisch, S. (2007b). Splintering urban populations: Emergent landscapes of reurbanisation in four European cities. Urban Studies, 44(4), 651-677. https:// doi.org/10.1080/00420980601185544

Catalàn, B., Saurì, D., \& Serra, P. (2008). Urban sprawl in the Mediterranean? Patterns growth and change in the Barcelona Metropolitan Region 1993-2000. Landscape and Urban Planning, 85(34), 174-184. https://doi.org/10.1016/j.landurbplan.2007.11.004

Cellamare, C. (Ed.). (2016). Fuori raccordo. Abitare l'altra Roma. Donzelli Editore.

Champion, A. G., \& Congdon, P. D. (1988). Recent population trends for Greater London. Population Trends, 53, 11-17.

Champion, T. (2001). Urbanization, Suburbanization, Counterurbanization and Reurbanization. In R. Padison (Ed.), Handbook of Urban Studies. SAGE.

Cheshire, P. C. (2006). Resurgent cities, urban myths and policy hubris: What we need to know. Urban Studies, 43(8), 1231-1246.

Clementi, A., \& Perego, F. (Eds.). (1983). La metropoli “spontanea”. Il caso di Roma 1925-1981. Edizioni Dedalo.

Clough Marinaro, I., \& Thomassen, B. (Eds.). (2014). Global Rome. Changing faces of the eternal city. Indiana University Press.

Commission, E. (2019). The cultural and creative European cities monitor (2019th ed.). Publications Office of the European Union.

Commission, E. (2020). Report on the quality of life in the European cities 2020. Publications Office of the European Union.

Conforti, L., Mela, A., \& Perino, G. (2013). Aree urbane e tendenze insediative nell'Italia del Nord. Ires Piemonte.

Couch, C., Fowles, S., \& Karecha, J. (2009). Reurbanization and housing markets in the central and inner areas of Liverpool. Planning Practice \& Research, 24(3), 321-341.

Couch, C., Leontidou, L., \& Petschel Held, G. (Eds.). (2007). Urban sprawl in Europe. Landscapes, landuse change and policy. Blackwell.

Courgeau, D. (1985). Interaction between spatial mobility, family and career life-cycle: A French survey. European Sociological Review, 1(2), 139-162.

Crisci, M. (2010). Italiani e stranieri nello spazio urbano. Dinamiche della popolazione di Roma. FrancoAngeli.

Crisci, M. (2019). The social impact of urban sprawl in Mediterranean cities. The case of Rome. In M. Crisci \& S. Lucciarini (Eds.), Governing inequalities Inclusion and exclusion processes in the Mediterranean area, from national to city levels (pp. 265-285). Aracne.

Crisci, M., \& Santacroce, A. (2019). Rome after sprawl: A return to the compact city? In E. Canepari \& M. Crisci (Eds.), Moving around in town. Practises, pathways and contexts of intra-urban mobility from 1600 to the present day (pp. 63-79). Viella.

D’Albergo, E. (2015). Perchè è difficile costruire la città metropolitan a Roma: un'interpretazione sociologica. Working Paper Urban@it, Background Papers, n.1.

D’Albergo, E., Lefèvre, C., \& Ye, L. (2018). For a political economy of metropolitan scale: The role of public-private relations. Territory, Politics, Governance, 6(2), 182-198.

Della Seta, P., \& Della Seta, R. (1988). I suoli di Roma. Uso e abuso del territorio nei cento anni della capitale. Editori Riuniti. 
Díaz-Pacheco, J., \& García-Palomares, J. C. (2014). Urban sprawl in the Mediterranean urban regions in Europe and the crisis effect on the urban land development: Madrid as study case. Urban Studies Research. https://doi.org/10.1155/2014/807381

EEA (2006). Urban sprawl in Europe. The ignored challenge, EEA Report, 10, Copenhagen: European Environment Agency.

Florida, R. (2011). The great reset: How the post-crash economy will change the way we live and work. Harper Collins.

García-Coll, A., \& López-Villanueva, C. (2018). The impact of economic crisis in áreas of sprawl in Spanish cities. Urban Science, 2(4), 113.

Gil-Alonso, F., Bayona-i-Carrasco, J., \& Pujadas-i-Rúbies, I. (2016). From boom to crash: Spanish urban areas in a decade of change (2001-2011). European Urban and Regional Studies, 23(2), 198-216. https://doi.org/10.1177/0969776413498762

Guerrieri, G., Festa, M., \& Ghiraldo, E. (2018). Il ciclo del mercato residenziale, le differenze per struttura di mercato e il ruolo del credito. Quaderni Dell'osservatorio Del Mercato Immobiliare, 7, $8-44$.

Haase, A., Kabisch, S., Steinführer, A., Bouzarovski, S., Hall, R., \& Ogden, P. (2010). Emergent spaces of reurbanisation: Exploring the demographic dimension of inner-city residential change in a European setting. Population, Space and Place, 16(5), 443-463.

Hall, R., \& Ogden, P. (2003). The rise of living alone in inner London: Trends among the population of working age. Environment and Planning A, 35(5), 871-888. https://doi.org/10.1068/a3549

Horowitz, J. (2018, December 24). Rome in Ruins. The New York Times. https://www.nytimes.com/2018/ 12/24/travel/rome-pollution-trash.html.

Inrix. (2019). Global Traffic Scorecard Ranking. https://inrix.com/scorecard/.

Insolera, I. (2011). Roma moderna. Einaudi.

Kabisch, N., Haase, D., \& Haase, A. (2019). Reurbanisation: A long-term process or a short-term stage? Population, Space and Place, 25(8), e2266.

López-Gay, A. (2014). Population growth and re-urbanization in Spanish inner cities: The role of internal migration and residential mobility. Revue Quetelet, 1(2), 67-92. https://doi.org/10.14428/rqj2014. 02.01 .03

Módenes, J. A., \& López-Colás, J. (2014). Recent demographic change and housing in Spain: Towards a new housing system? Revista Española De Investigaciones Sociológicas, 148, 103-134.

Montalto, V., Moura, C. J. T., Langedijk, S., \& Saisana, M. (2019). Culture counts: An empirical approach to measure the cultural and creative vitality of European cities. Cities, 89, 167-185.

Moreno, C., Allam, Z., Chabaud, D., Gall, C., \& Pratlong, F. (2021). Introducing the "15-Minute City": Sustainability, resilience and place identity in future post-pandemic cities. Smart Cities, 4(1), 93-111.

Morrison, P., \& Clark, W. A. V. (2011). Internal migration and employment: Macro flows and micro motives. Environment and Planning A, 43(10), 1948-1964.

Mulder, C. H. (2007). The family context and residential choice. A challenge for new research. Population, Space and Place, 13(4), 265-278. https://doi.org/10.1002/psp.456

Muñoz, F. (2003). Lock living: Urban sprawl in Mediterranean cities. Cities, 20(6), 381-385. https://doi. org/10.1016/j.cities.2003.08.003

Musterd, S. (2006). Segregation, urban space and the resurgent city. Urban Studies, 43(8), 1325-1340.

Myers, D. (Ed.). (1990). Housing demography: Linking demographic structure and housing markets. University of Wisconsin Press.

Nijkamp, P., \& Kourtit, K. (2013). The "New Urban Europe": Global challenges and local responses in the urban century. European Planning Studies, 21(3), 291-315. https://doi.org/10.1080/09654313. 2012.716243

Nyström, J. (1992). The cyclical urbanization model: A critical analysis. Geografiska Annaler, 74(2), 133-144. https://doi.org/10.2307/490569

OECD. (2012). Compact city policies: A comparative assessment. OECD.

Ogden, P. E., \& Hall, R. (2000). Households, reurbanisation and the rise of living alone in the principal French cities 1975-1990. Urban Studies, 37(2), 367-390. https://doi.org/10.1080/0042098002230

Palomares-Linares, I., \& van Ham, M. (2016). Understanding the effects of homeownership and regional unemployment levels on migration during the economic crisis in Spain. IZA Discussion Papers, No. 10232. Institute for the Study of Labor (IZA).

Petsimeris, P. (2002). Counter-urbanization in Italy. In: H. S., Geyer (Ed.), International Handbook of Urban Systems, chapter 9, Edward Elgar Publishing. 
Povoledo, E. (2014, December 11). Italy gasps as inquiry reveals Mob's Long Reach. The New York Times. https://www.nytimes.com/2014/12/12/world/italy-gasps-as-inquiry-reveals-mobs-long-reach. html.

Pujadas, I., López-Villanueva, C., \& Bayona, J. (2016). Residential mobility in the Barcelona metropolitan region during the present economic crisis. Portuguese Journal of Social Sciences, 15(1), 91-110.

Rérat, P. (2012). The new demographic growth of cities: The case of reurbanisation in Switzerland. Urban Studies, 49(5), 1107-1125. https://doi.org/10.1177/0042098011408935

Rérat, P. (2019). The return of cities: The trajectory of Swiss cities from demographic loss to reurbanization. European Planning Studies, 27(2), 355-376. https://doi.org/10.1080/09654313.2018.1546832

Roma Capitale. (2015). La revisione anagrafica. Allineamento tra popolazione anagrafica e popolazione calcolata post Censimento 2011. Ragioneria Generale, Direzione Sistemi di pianificazione e controllo finanziario, U.O. Statistica.

Salvati, L., \& Gargiulo Morelli, V. (2014). Unveiling urban sprawl in the Mediterranean region: Towards a latent urban transformation? International Journal of Urban and Regional Research, 38(6), 19351953. https://doi.org/10.1111/1468-2427.12135

Sonnino, E., Bertino, S., Casacchia, O., Crisci, M., D’Orio, G., \& Rosati, R. (2011). Popolazione e previsioni demografiche nei municipi di Roma Capitale. Dinamiche attuali e prospettive fino al 2024. Gangemi Editore.

Tocci, W. (2020). Roma come se. Alla ricerca del futuro per la capitale. Donzelli Editore.

Van de Kaa, D. J. (1987). Europe's second demographic transition. Population Bulletin, 42(1), 1-59.

Van den Berg, L., Drewett, R., Klaassen, L. H., Rossi, A., \& Vijverberg, C. H. T. (1982). Urban Europe: A study of growth and decline. Pergamon.

Publisher's Note Springer Nature remains neutral with regard to jurisdictional claims in published maps and institutional affiliations. 